\title{
EXPLORING THE EFFECT OF BUSINESS PERFORMANCE ON SMALL AND MICRO ENTERPRISES TO ESTABLISH AN INTERNAL CONTROL COMMITTEE: A BINARY LOGISTIC REGRESSION MODEL
}

\author{
Atilla BÜYÜKÇOBAN* \\ Gülümser ÜNKAYA ${ }^{* *}$ \\ Tuğba ALTINTAŞ ${ }^{* * *}$
}

\begin{abstract}
This study examines how business performance affects small and micro enterprises' decision on establishing an internal control committee. By observing a sample of 186 small and micro firms in Turkey, we test the claim that small and micro enterprises financial problems obstruct establishing an internal control committee. We measure business performance by financial and non-financial indicators obtained from sample firms' accounting reports and information system. Then, the effect of business performance on establishing an internal control committee is studied by a binary logistic regression analysis. As a result of the analysis it is explored that there was a statistically significant positive effect of business performance on "establishing an internal control committee" decision and the claim that financial problems obstruct establishing an internal control committee is verified.
\end{abstract}

Keywords: Internal Control Committee, Business Performance, Small and Micro Enterprises, Binary Logistic Regression

JEL Classification: M42, M10, C12, C13

* Prof. Dr., Istanbul Aydin University, PhD Candidate, atillabuyukcoban@gmail.com

** Doç. Dr., Istanbul Aydin University, gulumserunkaya@aydin.edu.tr

*** Uskudar University, tugba.altintas@uskudar.edu.tr 


\title{
İŞLETME PERFORMANSININ KÜÇÜK VE ORTA ÖLÇEKLİ İ̧SLETMELERIN İÇ KONTROL KOMITTESI KURMASI ÜZERINNDEKI ETKISINININ ARAŞTIRILMASI: İKILİ LOJISTIK REGRESYON MODELI
}

\begin{abstract}
Özet
Bu çalışma işletme performansının küçük ve orta ölçekli işletmelerin iç kontrol komitesi kurma kararını nasıl etkilediğini incelemektedir. Türkiye'den seçilen 186 küçük ve orta ölçekli işletme gözlemlenerek, bu işletmelerin finansal sorunlarının iç kontrol komitesi kurmayı engellediği iddiası test edilmektedir. İsletme performansı, gözlemlenen işletmelerin muhasebe raporları ve bilgi sistemlerinden elde edilen finansal ve finansal olmayan göstergelerle ölçülmüştür. Daha sonra işletme performansının iç kontrol komitesi kurma kararına etkisi ikili lojistik regresyon analiziyle araşttrılmıştır. Analiz sonucunda işletme performansının iç kontrol komitesi kurma kararı üzerinde pozitif yönlü anlamlı etkiye sahip olduğu görülmüş, finansal sorunların iç konrol komitesi kurmayı engellediği iddiası doğrulanmıştır.
\end{abstract}

Anahtar Kelimeler: İçkontrol komitesi, işletme performansı, küçük ve orta ölçekli işletmeler, ikili lojistik regresyon analizi

JEL Sınıflaması: M42, M10, C12, C13

\section{Introduction}

In today's global world small and micro enterprises (SMEs) are the biggest contributors to employment across countries and this contribution is greater in low-income countries than the higher income ones. SMEs with 250 employees or fewer generate $86 \%$ of the jobs. Their contribution is higher (93\%) in the countries that had a net positive job creation across all firms in the country ${ }^{1}$. In Turkey are the enterprises whose number of employees are less than 250 and annual turnover or annual balance sheet does not exceed 25 million Turkish Liras are determined as SMEs ${ }^{2}$. According to Turkish Statistical Institute (2013), SMEs constitute 99.9\% of total number of enterprises,

$76 \%$ of employment, $53 \%$ of wages and salaries, $63 \%$ of turnover, $53.3 \%$ of value added at factor cost and $53.7 \%$ of gross investment in tangible goods. The proportion of SMEs which had 1-249 employees was $62.6 \%$ for exports in 2012. The rate of micro enterprises (1-9 employees) is $20.6 \%$, small enterprises (10-49 employees) is $24.3 \%$, medium-sized enterprises (50-249 employees) is $17.7 \%$ and large enterprises $(250+)$ is $37.2 \%$ in exports. Although they have a significant role in global economy, especially in developing countries SMEs face excessive financial barriers which keep them from developing. The costs and risks of serving SMEs are

1 M. Ayyagari et al (2011). Small vs. Young Firms Across the World: Contribution to Employment, Job Creation, And Growth. Policy Research Working Paper, April, s. 5631.

2 KOSGEB (2012). Enhancing the Competitiveness of SMEs in Turkey Country Report, Ankara. 
frequently perceived to be too high by commercial finance. Microfinance loans, on the other hand, are too small to meet SME capital needs. These result in SMEs to face a financing gap. Financing for SMEs is limited, particularly when compared to commercial debt for large firms and microfinance ${ }^{3}$. Because of the financial limitations, most SMEs prevent the owners/CEOs of SMEs to relinquish many roles like ensuring an internal control committee. This is already a problem in current situation since SMEs usually will not be willing to pay too much to hire a highly qualified internal controller ${ }^{4}$. No matter what the size of the enterprise is, a vast majority of data presented to analyze and make a decision about enterprises is provided by the accounting system. Many groups and foundations are closely interested in the information and data provided by the accountancy, as it is a tool of management. The activity of internal control committee has a great importance on SMEs' confidence future. Small businesses are expected to concern on internal controls to protect their assets and reduce the risk of fraud. Additionally, the growing awareness of fraud has caused investors and other companies to focus on stronger internal controls at the smaller, private companies. Due to the business scale, human resource, financial and its own conditions ect, many SMEs under the ownership and franchise's restrictions, unwilling to establish the standard internal control committee. As mentioned before they believe that establishing an internal control committee is a high cost method, which will bring heavy burden to the enterprise and may be without significant results cannot compare with the managers manage all aspects of business directly ${ }^{5}$. Less logistic and structured condition of internal control committee in SMEs does not diminish the value and effectiveness of internal control. Therefore, the positive impact of internal control committee on organizational effectiveness, productivity and prolificacy cannot be ignored, both in small, and big enterprises ${ }^{6}$.That's why some SMEs have been establishing and internal control committee by accepting its cost and they think the benefit is greater than the cost. In accordance with two perspectives, we aimed to determine how SMEs decide to establish an internal control committee and which factors related to business performance significantly affect their decision.

\section{Literature Review}

It is a known fact that internal control over financial reporting has long been recognized as an important feature of a company ${ }^{7}$. The definition of internal control systems reveals that it is not fundamentally different from management control, which has an essential component of control such as planning, organizing, staffing and directing ${ }^{8}$. By establishing an internal control

3 WORLD BANK (2008). Finance for All? A World Bank Policy Research Report, Washington.

4 NEW STRAITS TIMES (2012). Let Internal Auditors Sit in at High-Level Meetings, 0ct 24 issues.

5 Jiang, L., Li, X. (2010). Discussions On the Improvement of the Internal Control in SMEs. International Journal of Business and Management, 5(9), s. 214-216.

6 F. M. Sgardea, F.M. (2009). Risk Management and The Internal Control Systems Promoted by COSO in The Context of Financial Crisis. Metalurgia International, Vol. 15, s. 53-56.

7 Kinney Jr, W.R. (2001). Accounting Scholarship: What Is Uniquely Ours? The Accounting Review, 76(2), s. $275-284$.

8 Chambers et al (1987). International Auditing. 
committee SMEs could clearly follow that process. Reviewing and evaluating the adequacy and effectiveness of an organization's internal control system and the quality of performance in carrying out assigned responsibilities is representative of several primary core activities of internal control committee work. The purpose of the review of the adequacy of the internal control is to ascertain whether the established internal control committee provides reasonable assurance that the organizations' objectives and goals will be met efficiently and economically ${ }^{9}$.

In 1992, The Committee of Sponsoring Organizations were charged by the Treadway Commission to develop an integrated guidance on Internal Control. As a result of this, a framework for designing, implementing and evaluating internal control for organizations was released. The COSO Framework was designed to help businesses establish, assess and enhance their internal control. The importance of Internal Control in the Operations and Financial Reporting of an entity cannot be over-emphasized as the existence or the absence of the process determines the quality of output produced in the Financial Statements. A present and functioning Internal Control process provides the users with a "reasonable assurance" that the amounts presented in the Financial Statements are accurate and can be relied upon for informed decision making. The COSO Integrated Framework for Internal Control has five (5) components which include ${ }^{10}$ :

Control Environment: The control environment is the set of standards, processes, and structures that provide the basis for carrying out internal control across the organization. The board of directors and senior management establish the tone at the top regarding the importance of internal control including expected standards of conduct.

Risk Assessment: Every entity faces a variety of risks from external and internal sources. Risk assessment involves a dynamic and iterative process for identifying and assessing risks to the achievement of objectives. Risks to the achievement of these objectives from across the entity are considered relative to established risk tolerances.

Control Activities: Control activities are the actions established through policies and procedures that help ensure that management's directives to mitigate risks to the achievement of objectives are carried out. Segregation of duties is typically built into the selection and development of control activities. Where segregation of duties is not practical, management selects and develops alternative control activities.

Information and Communication: Information is necessary for the entity to carry out internal control responsibilities to support the achievement of its objectives. Management obtains or generates and uses relevant and quality information from both internal and external sources to support the functioning of internal control.

9 Fadzil, F. et al (2005). Internal Auditing Practices and Internal Control System, Managerial Auditing Journal, 20(8), s. 844-866.

10 COSO (2017). https://www.coso.org/Documents/990025P-Executive-Summary-final-may20.pdf, Access Date (15.10.2017) 
Monitoring Activities: Ongoing evaluations, separate evaluations, or some combination of the two are used to ascertain whether each of the five components of internal control, including controls to effect the principles within each component, is present and functioning. Ongoing evaluations, built into business processes at different levels of the entity, provide timely information. Separate evaluations, conducted periodically, will vary in scope and frequency depending on assessment of risks, effectiveness of ongoing evaluations, and other management considerations. Findings are evaluated against criteria established by regulators, standard-setting bodies, or management and the board of directors, and deficiencies are communicated to management and the board of directors as appropriate.

In Turkey's SMEs internal control activity is waged by establishing an internal control committee or outsourcing this service. When outsourced, coordination and management of that internal control activities should be in charge of the internal control manager of the company.

Internal control is a process, affected by an entity's board of directors, management and other personnel, designed to provide reasonable assurance regarding the achievement of objectives in various categories. Internal control is a key element of the reliability of financial reporting, effective and efficient entity operations, and compliance with laws and regulations. Internal control increases the efficiency of operations by applying the standardized procedures; it adds value to control processes. Internal control provides the reliability of financial reporting; supports management in making right financial decisions and eliminates or identifies fraudulent acts within the entity. Internal control reinforces and ensures compliance with laws and regulations. in other words, it prevents the entity from any financial or property loss, inaccurate decision making, fraud, loss of income and failure in reaching goals that may be resulted from the lack of internal controls. The role of internal control committee, therefore, provides support for management in safeguarding company assets, elimination of any income and resource loss, making goal-oriented and accurate decisions, identifying and preventing fraud ${ }^{11}$. The importance of establishing an internal control committee is also explained by Sarbanes-Oxley Act (SOX). Taking into consideration the relevance of the internal control from the perspective of internal auditors' activity, since 1978 The Institute of Internal Auditors in USA has presented as objectives of the internal control "the security of assets, quality of information, the compliance with the directives and optimization of resources". In answer to the effects of Enron's famous bankruptcy, as well as of other corporate divergences, in 2002 the American Congress adopted the highest reforms for the internal control, for the corporate governance by SOX. SOX of 2002 is an act passed by U.S. Congress in 2002 to protect investors from the possibility of fraudulent accounting activities by corporations. The SOX Act mandated strict reforms to improve financial disclosures from corporations and prevent accounting fraud. The SOX Act was created in response to accounting malpractice in the early 2000s, when public scandals such as Enron Corporation, Tyco International plc, and WorldCom shook investor confidence in financial statements and demanded an overhaul of regulatory

11 Uzun, A.K. (2009). The Role of Internal Audit in Internal Control Quality in Corporate Organizations, 3rd International Symposium on Auditing in Turkey, Istanbul, 12-13 October. 
standards ${ }^{12}$. SOX, which stipulates that companies must establish an internal control committee to regulate positioning, independence, and the relationship with accountants ${ }^{13}$. In Section 404 , this regulation imposes "the responsibility of the management to create and maintain an adequate structure of the internal control and procedures of financial reporting" ${ }^{14}$. But, it is not mandatory for small and micro enterprises.

For SMEs an internal control system is also defined as the policies and procedures put in place to ensure the protection of an organization's assets and the reliability of financial reporting. Establishing an internal control committee can provide only reasonable assurance not absolute assurance regarding the achievement of an organization's objectives. Implementing a proper system with a committee will help the organization's operations become more effective and efficient ${ }^{15}$. The issue with internal control of organizations is ensuring the efficiency and effectiveness of activities, reliability of information, compliance with applicable laws, and timeliness of financial reports ${ }^{16}$. A proper internal control committee ensures that the organization's managers would utilize the financial resources in a way that will safeguard the interests of contributors ${ }^{17}$. It includes policies and procedures on controls such as withdrawal applications for funds and grant accounts, bank and cash, purchases, payments and monitoring, evaluations and reporting. Thus, to have a successful organization, it requires a proper accounting record and appropriate management control system ${ }^{18}$. Effective internal control committee in SMEs was lead to successful of the business and it also a fundamental and important step in reducing employee theft ${ }^{19}$. Studied by Bronson et al., (2006) find that, internal control was effective on SMEs and it is a tool to measure the SMEs performance. Furthermore, their study also identified that, there is a significant positive relationship between internal control and small business performance. Within a firm, better internal control should yield more reliable on internal data such as inventories, payables and performance measure, thus leading to better internal decision making, improved operations, and lower employee fraud ${ }^{20}$.

12 Foster, B.P. et al (2007). Audit Costs, Material Weaknesses Under SOX Section 404, Managerial Auditing Journal, 22(7), s. 661-673.

13 Wang, M.C. et al (2016). Relations Among Audit Committee Establishment, Information Transparency and Earnings Quality: Evidence from Simultaneous Equation Models, Quality \& Quantity, 50(6), s. 2417-2431.

14 Marchetti, A.M. (2005). Beyond Sarbanes-Oxley Compliance: Effective Enterprise Risk Management, New Jersey: John Wiley and Sons, Inc.

15 Sulaiman, M. et al (2008). Internal Control Systems in West Malaysia's State Mosques, American Journal of Islamic Social Sciences, 25(1), s.63.

16 Jokipii, A. (2010). Determinants and Consequences of Internal Control in Firms: A Contingency Theory Based Analysis, Journal of Management \& Governance, 14(2), s. 115-144; Changchit, C. et al (2001). Supporting Managers' Internal Control Evaluations: An Expert System and Experimental Results, Decision Support Systems, 30(4), s. 437449.

17 Sulaiman, M. et al (2008), s.63.

18 Sundgren, S., Svanström, T. (2013). Audit Office Size, Audit Quality and Audit Pricing: Evidence from Small - and Medium-Sized Enterprises, Accounting and Business Research, 43(1), s. 31-55.

19 Snyder, N. H. et al (1989). Using Internal Controls to Reduce Employee Theft in Small Businesses, Journal of small business management, 27(3), s. 48.

20 Doyle, J.T. et al (2007). Accruals Quality and Internal Control Over Financial Reporting, The Accounting Review, 82(5), s. 1141-1170; Ashbaugh-Skaife, H. et al (2009). The Effect of SOX Internal Control Deficiencies On Firm Risk 
In today's business world is highly emphasized on business performance. In order to measure business performance different criteria have been used so far. Dixon et al. (1990) said that appropriate performance measures are those which enable organizations to direct their actions towards achieving their strategic objectives. Reid and Ashelby (2002) contends that performance is measured by either subjective or objective criteria, arguments for subjective measures include difficulties with collecting qualitative performance data from small firms and with reliability of such data arising from differences in accounting methods used by firms. In order to survive and succeed in a competitive market, firms must focus on maximizing profit or they will eventually be driven out of business ${ }^{21}$. John (2011) supports this claim by saying that only efficient firms stay in the market, and that less productive firms will eventually exit many markets. Performance measures provide a mechanism for the organization to manage its financial and non-financial performance. Financial measures are related to economic factors such as profitability and sales growth (e.g. return on investment, return on sales and return on equity) and operational measures are related to non-financial success factors such as quality, market share, satisfaction, new product development and market effectiveness. Another classification in the performance measure includes objective and subjective measures. Objective performance measures refer to quantified indicators. They are generally financial indicators and obtained from organizations. On the other hand, subjective measures depend on judgmental assessments of respondents and these indicators cover both financial and non - financial indicators ${ }^{22}$. Wilks and Imblelman (2004) found out that objective performance measures include indicators such as profit growth, revenue growth, return on capital employed. Financial consultants Stern Stewart and Co. created Market Value Added (MVA), a measure of the excess value a company has provided to its shareholders over the total amount of their investments. This ranking is based on some traditional aspects of financial performance including: total returns, sales growth, profit growth, net margin, and return on equity. Morris (2011) discussed accounting based performance using three indicators: return on assets (ROA), return on equity (ROE), and return on sales (ROS). Each measure is calculated by dividing net income by total assets, total common equity, and total net sales, respectively ${ }^{23}$. According to study of Papadognas (2007) firms' profitability is positively influenced by firm size ${ }^{24}$. Lee (2009) examines the role that firm size plays in profitability ${ }^{25}$. Brah et al (2000) examine how business performance differs from service to manufacturing sector ${ }^{26}$.

and Cost of Equity. Journal of Accounting Research, 47(1), s. 1-43.

21 Dutta, P.K., Radner, R. (1999). Profit Maximization and The Market Selection Hypothesis, The Review of Economic Studies, 66(4), s. 769-798.

22 Benito, O.G., Benito, J.G. (2005). Cultural Vs. Operational Market Orientation and Objective Vs. Subjective Performance: Perspective of Production and Operations, Industrial marketing management, 34(8), s. 797-829.

23 Morris, J.J. (2011). The Impact of Enterprise Resource Planning (ERP) Systems On the Effectiveness of Internal Controls Over Financial Reporting, Journal of Information Systems, 25(1), s. 129-157.

24 Papadogonas, T.A. (2006). The Financial Performance of Large and Small Firms: Evidence from Greece, International Journal of Financial Services Management, 2(1-2), s.14-20.

25 Lee, J. (2009). Does Size Matter in Firm Performance? Evidence from US Public Firms, International Journal of the economics of Business, 16(2), s. 189-203.

26 Brah, S.A. et al (2000). TQM and Business Performance in The Service Sector: A Singapore Study, International Journal of Operations \& Production Management, 20(11), s. 1293-1312. 
Habib and Victor (1991) also compare manufacturing and service sector in terms of business strategy, structure and performance 27 .

By referring above indicators, to evaluate our sample SMEs in terms of business performance we measure their ROA and ROS as financial indicators. Since we couldn't collect data on shareholders' equity ROE is not included. We additionally use company size (number of employees) and sector as non-financial performance indicators. Thus, we have a data set used for explaining the decision on establishing an internal control committee (DEICC).

\section{Material and Method}

In this study we conduct a survey among owners, managers, and accounting - finance professionals of SMEs in Istanbul, Turkey. Population includes all SMEs in Istanbul. Because of the time and bugdet constraint, it's not possible to observe all population or use the simple random sampling method, we select a sample of 186 SMEs by the judgement sampling method. Judgement sampling is widely used for social research even in accounting and auditing ${ }^{28}$. Since most of the SMEs are in Istanbul according to TEPAV ${ }^{29}$, we think that sample represents population well for our case study. Due to the main goal of this research, the following model is introduced:

DEICC $=\mathrm{f}($ ROA, ROS, company size, sector $)$

In the model, DEICC is the dependent variable $(\mathrm{y})$ and it is a binary variable takes the value of 1 if the responding owner-manager has answered "yes" to the question "Do you prefer establishing an internal control committee?", and 0 if the answer to this question is "No".

Sector, is a qualitative explanatory variable with two categories; service, manufacturing.

Size is a quantitative explanatory variable takes different numerical values as number of employees.

ROA for the year 2016 is a quantitative explanatory variable takes different numerical values.

ROS for the year 2016 is a quantitative explanatory variable takes different numerical values as number of employees.

After collecting and preparing data, we apply A Binary Logistic Regression Analysis by using SPSS 21 . Given that $\mathrm{p}=$ the probability of DEICC, then the function that is modelled as the outcome in a logistic regression is:

$\operatorname{Logit}(p)=\ln \frac{p}{1-p}$

27 Habib, M.M., Victor, B. (1991). Strategy, Structure, and Performance of US Manufacturing and Service Mncs: A Comparative Analysis, Strategic Management Journal, 12(8), s. 589-606.

28 Yıldırım, H., İnel, M. (2012). Muhasebe Denetiminde Örnekleme Tekniklerinin Değerlendirilmesi Üzerine Bir İnceleme, İktisadi ve İdari Bilimler Dergisi, 32(1), s.261-276.

29 TEPAV (2017). http://www.tepav.org.tr/tr/haberler/s/3978, Access date (15.09.2017). 
Where $\frac{p}{1-p}=\frac{\text { favorable DEICC }}{\text { unfavorable } D E I C C}=$ the odds ratio

The logistic model is therefore

Logit $(p)=a+b_{1} x_{1}+b_{2} x_{2}+b_{3} x_{3}+b_{4} x_{4}+e$

Where $\mathrm{a}$ is the estimated constant and b's are the estimated regression coefficients, and $\mathrm{e}$ is the residual term.

\section{Findings}

When we observe respondents -well informed about properties of the internal control system, duties and responsibilities of an internal control committee - according to their answers to the question "Do you prefer establishing an internal control committee?", it was seen that $57 \%$ of them has answered "Yes" and 43\% "No".

According to distribution by sector, $54 \%$ of firms are from service and $46 \%$ manufacturing sector. Their approximate mean ROA and ROS are respectively $3,03 \%$ and $0,18 \%$ with standard deviations 0,08 and 0,02. The minimum and the maximum values for the number of employees are respectively 10 and 2500 with a mean of 109 and a standard deviation of 287 .

Table 1 includes the Chi-Square goodness of fit test. It has the alternative hypothesis that at least one coefficient is different from zero. Here we see a chi-square statistic as 31,4 with $p=0,000<0,05$ which makes the model significant and we don't reject that alternative hypothesis, we decide at least one coefficient is different from zero. Nagelkerke's R Square is 0,236 which indicates that the model is good but not great. Thus we can interpret that $24 \%$ probability of the event preferring an internal control committee is explained by the logistic model.

Table I: Summary Measures of the Model

\begin{tabular}{|l|l|l|}
\hline Omnibus Tests of Model Coefficients & Explanation Power of the Model \\
\hline Chi-square & $\mathbf{p}$ & Nagelkerke R Square \\
\hline 31,391 & 0,000 & 0,236 \\
\hline
\end{tabular}

Table 2 contains the classification results. As it seen, our model is now correctly classifying sample companies $70 \%$. Then, observed and predicted decision classes are fitting well. 
Table 2: Classification Table

\begin{tabular}{|c|c|c|c|c|}
\hline \multirow{3}{*}{ Observed } & & \multicolumn{3}{|c|}{ Predicted } \\
\hline & & \multicolumn{2}{|c|}{ DEICC } & \multirow{2}{*}{$\begin{array}{l}\text { Percentage } \\
\text { Correct }\end{array}$} \\
\hline & & YES & NO & \\
\hline \multirow[b]{2}{*}{ DEICC } & YES & 78 & 18 & 81,3 \\
\hline & NO & 30 & 35 & 53,8 \\
\hline \multicolumn{2}{|c|}{ Overall Percentage } & & & 70,2 \\
\hline
\end{tabular}

Table 3 is the most important one for our logistic regression analysis. This table provides the regression coefficient (B), the Wald statistic (to test the statistical significance) and the allimportant Odds Ratio (Exp (B)) for each variable category.

It shows the regression function as;

Logit $(\mathrm{p})=1,569+001 \mathrm{x}_{1}-0,505 \mathrm{x}_{2}+0,957 \mathrm{x}_{3}+0,441 \mathrm{x}_{4}+\mathrm{e}$.

Now, we can predict the probability of a SME deciding an internal control committee.

The table also includes the test of significance for each of the coefficients in the logistic regression model. For small samples the $t$-values are not valid and the Wald statistic should be used instead. As we can see, except sector, all coefficients are significant with p values less than 0,05.

Table 3. Coefficients' Significance Test

\begin{tabular}{|l|l|l|l|}
\hline & Wald Statistic & P & $\operatorname{Exp}(\mathrm{B})$ \\
\hline Size & 3,848 &, 050 & 1,001 \\
\hline Sector & 1,796 &, 180 &, 604 \\
\hline ROS & 16,805 &, 000 &, 384 \\
\hline ROA & 4,032 &, 045 & 1,554 \\
\hline
\end{tabular}

When we interpret the effect of each independent variable on preferring an internal control committee by looking at logistic regression coefficients;

- A one-unit increase in number of employees the log odds of preferring an internal committee (versus not preferring) increases by 1,001.

- Since the sector's logistic regression coefficient is not significant, sector doesn't affect the internal control committee preference.

- A one-unit increase in ROS the log odds of preferring an internal committee (versus not preferring) increases by 0,384 .

- A one-unit increase in ROA the log odds of preferring an internal committee (versus not preferring) increases by 1,554 .

Thus, except sector, we see the positive effect of business performance on DEICC. 


\section{Conclusion}

In this paper we explore the relationship between business performance and decision on establishing an internal control committee. Using a 186 small and micro companies in Turkey, we see that business performance positively affects the preference of SMEs to establish an internal control committee.

According to findings, business performance indicators - Return on Assets and Return on Sales - based on respondent SMEs' accounting reports show that Turkey's SMEs are not productive enough although none of them make a loss. Then, the attitude on establishing an internal control committee to be a high-cost activity is supported by that finding. Additionally, we also explore that when Return on Assets and Return On Sales are increasing, the probability that establishing an internal control committee is increasing. If the company is financially strong enough, internal control committee establishment resource will be allocated. Otherwise, this activity is just a cost element for a company.

We know that large companies with thousands of employees in multiple offices have a harder time protecting themselves from internal fraud. But small businesses encounter large losses from fraud compared to larger organizations. Businesses with fewer than 100 employees accounted for the highest percentage of fraud instances -nearly 29\% - reported in the 2014 Report to the Nations by the Association of Certified Fraud Examiners (ACFE). Correspondingly, we find a positive effect of company size on the preference of establishing an internal control committee. When the SME is getting larger, the probability that decision on establishing an internal control committee is also increasing. That's why fulfilling internal control procedures is impossible without an effective internal control system. According to larger SMEs owners and managers internal control procedures-known as separation of duties, policies and procedures, documentation, oversight and review and user access rights for information systems-require an internal control committee.

Finally, we don't see a significant relationship between sector and decision on establishing an internal control committee. Whatever the company has operations in any sector, trade or manufacturing, owners or managers are agree with each other about internal control system and its requirements.

In summary, Turkey's SMEs are mostly affected by financial indicators while deciding to establish an internal control committee. If they are unable to access enough financial resources, to establish an internal control committee is just a cost element as can be seen in related studies. But, when a SME is getting larger, fraud risk compels an internal control committee to establish. In fact, small businesses have less than 100 employees encounter large losses from fraud compared to larger organizations. In this way, no matter what the size of firm is, we recommend SMEs to establish an internal control committee and believe the benefit is greater than its cost. Otherwise, it's possible to take loss due to the lack of an internal control system. We hope the study which examines the 
effect of business performance on establishing an internal control committee to provide a suitable reference for relevant researchers, companies and further studies.

\section{References}

ASHBAUGH-SKAIFE, Hollis., Collins, Daniel W., Kinney, JR, William., Lafond Ryan (2009). The Effect of SOX Internal Control Deficiencies On Firm Risk And Cost of Equity, Journal of Accounting Research, 47(1), s.1-43.

AYYAGARI, Meghana., Demirgüç-Kunt, Aslı., Maksimovic, Vojislav (2011). Small vs. Young Firms Across The World, Policy Research Working Paper, s. 5631.

BRAH, Shaukat. A., Tee, Serene S.L., Madhu Rao (2000). TQM and Business Performance in the Service Sector: A Singapore Study, International Journal of Operations \& Production Management, 20(11), s. $1293-1312$.

CHAMBERS, Andrew (1987). International Auditing, United Kingdom.

CHANGCHIT, Chuleeporn., Holsapple, Clyde., Madden, Donald (2001). Supporting Managers' Internal Control Evaluations: An Expert System and Experimental Results, Decision Support Systems, 30(4), s. $437-449$

COSO (2017). https://www.coso.org/Documents/990025P-Executive-Summary-final-may20.pdf , Access Date (15.10.2017).

DOYLE, Jeffrey., Ge, Weili., McVay, Sarah (2007). Accruals Quality and Internal Control Over Financial Reporting, The Accounting Review, 82(5), s. 1141-1170.

DUTTA, Prajit K., Radner, Roy (1999). Profit Maximization and The Market Selection Hypothesis, The Review of Economic Studies, 66(4), s. 769-798.

FADZIL, Faudziah., Haron, Hasnah., Jantan, Muhamad (2005). Internal Auditing Practices and Internal Control System, Managerial Auditing Journal, 20(8), s. 844-866.

FOSTER, Benjamin P., William Ornstein., Trimbak Shastri (2007). Audit Costs, Material Weaknesses Under SOX Section 404, Managerial Auditing Journal, 22(7), s. 661-673.

GONZÁLEZ-BENITO, Óscar., González-Benito, Javier (2005). Cultural vs. operational market orientation and objective vs. subjective performance: Perspective of production and operations, Industrial marketing management, 34(8), s. 797-829.

HABIB Mohammed M., Victor, Bart (1991). Strategy, Structure, and Performance of Us Manufacturing and Service Mncs: A Comparative Analysis, Strategic Management Journal, 12(8), s. 589-606.

JIANG, Linjie., Li, Xuedong (2010). Discussions on the Improvement of the Internal Control in SMEs, International Journal of Business and Management, 5(9), s. 214-216.

JOKIPII, Annukka (2010). Determinants and Consequences of Internal Control In Firms: A Contingency Theory Based Analysis, Journal of Management \& Governance, 14(2), s. 115-144.

KINNEY Jr, William R. (2001). Accounting Scholarship: What Is Uniquely Ours?, The Accounting Review, 76(2), s. 275-284.

KOSGEB (2012). Enhancing the Competitiveness of SMEs In Turkey Country Report, KOSGEB, Ankara.

LEE, Jim (2009). Does Size Matter In Firm Performance? Evidence From US Public Firms, International Journal of the Economics of Business, 16(2), s. 189-203.

MARCHETTI, Anne M (2005). Beyond Sarbanes-Oxley Compliance: Effective Enterprise Risk Management, New Jersey: John Wiley and Sons, Inc. 
MORRIS, John J. (2011). The Impact of Enterprise Resource Planning (ERP) Systems On The Effectiveness Of Internal Controls Over Financial Reporting, Journal of Information Systems, 25(1), s. 129-157.

NEW STRAITS TIMES (2012). Let Internal Auditors Sit in at High-Level Meetings, 0ct 24 issues.

PAPADOGONAS, Theodore A. (2006). The Financial Performance of Large and Small Firms: Evidence From Greece, International Journal of Financial Services Management, 2(1-2), s. 14-20.

SGARDEA, Florinel Marian (2009). Risk Management and The Internal Control Systems Promoted by COSO In The Context of Financial Crisis, Metalurgia International, 15, s. 53-56.

SUNDGREN, Stefan., Svanström, Tobias (2013). Audit Office Size, Audit Quality And Audit Pricing: Evidence From Small - and Medium-Sized Enterprises, Accounting and Business Research, 43(1), s. 31-55.

SULAIMAN, Maliah., Siraj, Siti Alawiah., Ibrahim, S. H. Mohamed (2008). Internal Control Systems in West Malaysia’s State Mosques, American Journal of Islamic Social Sciences, 25(1), s. 63.

SNYDER, Neil H., Broome, O. Whitfield., Zimmerman, Karen (1989). Using Internal Controls to Reduce Employee Theft in Small Businesses, Journal Of Small Business Management, 27(3), s. 48.

TEPAV (2017) http://www.tepav.org.tr/tr/haberler/s/3978, Access date (15.09.2017).

UZUN, Ali Kamil (2009). The Role of Internal Audit in Internal Control Quality in Corporate Organizations, 3rd International Symposium on Auditing in Turkey, Istanbul, 12-13 October.

WANG, Mao Chang., Lee, Meng Han., Chuang, Jia Jiann (2016). Relations Among Audit Committee Establishment, Information Transparency and Earnings Quality: Evidence From Simultaneous Equation Models, Quality \& Quantity, 50(6), s. 2417-2431.

WORLD BANK (2008). Finance For All? A World Bank Policy Research Report, Washington.

YILDIRIM, Hakan., İnel, Mehmet(2012). Muhasebe Denetiminde Örnekleme Tekniklerinin Değerlendirilmesi Üzerine Bir İnceleme, İktisadi ve İdari Bilimler Dergisi, 32(1), s. 261-276. 
